\title{
Rethinking the Social Role of Nursing Through the Work of Donzelot and Foucault
}

\author{
Evy Nazon ${ }^{1}$, Amélie Perron ${ }^{2}$, Thomas Foth ${ }^{2}$ \\ ${ }^{1}$ Université du Québec en Outaouais, Nursing Science Department, Gatineau, Québec, Canada \\ ${ }^{2}$ University of Ottawa School of Nursing, Faculty of Health Sciences, Ottawa, Ontario, Canada
}

Cite as: CJCND 2019, 1(1), pp 49-58

\begin{abstract}
The history of nursing is often perceived as the history of a profession with charitable and philanthropic objectives of helping others live a healthy life. Many historians have celebrated the major role played by charitable women in nursing. Moving beyond this charitable and dedicated image of nurses, we argue that nursing, through "the social," became a pivotal component of the governance of the everyday lives of populations. As such, nursing became part of the evolving idea that all areas of life must be managed through a process of normalization that seeks to maximize the life of both the individual and the population. Populations thus became the focus of governmental projects. Jacques Donzelot's notion of invention of the social and Michel Foucault's concept of govenmentality make possible a reassessment of the conventional image of nurses, and in particular, that of charitable nurses.
\end{abstract}

Keywords: Nursing history; charity; philanthropy; governmentality; invention of the social

Charity is a form of social philosophy and action that aims to improve the human condition. Charity-and later, philanthropy-have underpinned practices of benevolence since European settlement in the 17th century in the United States and Canada (Elson, 2007; Gross, 2003). At that time, the state provided very little assistance to populations, and many charitable interventions were undertaken by voluntary associations and churches (Cohen, 2010; Hall, 1992). In the Christian tradition, charitable activities have always played an essential role. In private or public hospitals run by Catholic or Protestant organizations, women gave charitable care and involved themselves in the social problems of the poor and the sick.

Nursing historians often emphasize the role that nurses played in the health and hospital sectors, particularly with regard to the organization and provision of charitable care to individuals and populations (Paul, 1994; Petitat, 1989). However, the creation of charitable organizations such as hospitals not only ensured significant charitable services to communities but also significantly contributed to the shaping of society. Thus, in this paper, rather than focusing on the image of nurses as charitable and dedicated, we wish to examine the social role of nurses in charitable or philanthropic organizations and explore how, within these institutions, nursing became a decisive part of the governance of populations. Jacques Donzelot's notion of the invention of the social (Donzelot, 1994) and Michel Foucault's concept of governmentality (Foucault, 1994a) make possible a reassessment of the conventional image and charitable action of nurses. For the most part, the value of using these two concepts lies in their enhanced potential to highlight governing practices that involved non-state agents, like nurses who provided charitable and philanthropic social interventions. In so doing, we intend to politicize the role of these nurses.

\section{Charity and Philanthropy in Nursing}

Formal nursing charitable activities were carried out in many countries, particularly in the United States, France, Great Britain, and Canada, from the 17th century on. Private religious institutions, especially Catholic and Protestant-the two dominant religions in Western societies-were responsible for social services such as education and health care. Founded on moral and religious values, charity was about helping the 
poorest of the population (Elson, 2007; Hall, 1992). Religious sisters and deaconesses were "servants of Lord Jesus, servants of the sick for Jesus' sake, and servants among one another" (Foth, Kuhla, \& Benedict, 2014, p. 30).

During the 19th century, Protestant motherhouse systems and Catholic orders developed into leading forms of nursing organization. Religious communities founded hospitals, and later, nursing schools primarily to provide charitable care to the needy. Hospitals were perceived as moral institutions that supplied assistance, mercy, and salvation through the charitable work of religious sisters and later, lay nurses. These institutions emphasized the idea that charity should permeate all aspects of nursing (Kreutzer, 2010; Sioban, 2001). As a result, nursing work was regarded mainly as "charity service" based on the Christian faith and joining a nursing school meant that women vowed to dedicate their lives to the service of the sick, the poor, and the community as a whole. Charity, vocation, and self-sacrifice were seen as essential characteristics of women wanting to become nurses (O’Brien, 2008).

In France, Castel (1995) noted that Christian charity did not target all forms of poverty. Only those indigent people who it was thought deserved charity were selected-those who had the spiritual poverty of Pauper Christi-those deemed lazy and needy were left aside. According to Bremner (1956), philanthropic organizations in the United States put in place similar measures to sort out the poor: Help was offered to the "deserving" while the "undeserving" were ignored. Based on Foucault's analysis, charity work led to the creation of categories of people living in poverty (e.g., the "good" and "bad" poor) and the aim of charitable practices was to develop ways to encourage them to work in order to turn them into a useful workforce (Foucault, 1994a). For Foucault (1994b), Christian charity constituted a means of disciplining poor people. Such a perspective contradicts historical analyses in nursing that state that the desire to care for the poor was the core value of religious women who had to take care of the needy (Cohen, 2010; Paul, 1994; Petitat, 1989).

Foucault (1975) also noted that charity work has taken different forms over the centuries. Before the 17th century, charity was carried out through the internment of indigent people in hospices. During the 17th century, in what Foucault called the era of the "great confinement," charitable practices gained political, social, economic, and moral significance. With the rapid proliferation of poor people and beggars, charity houses also served as asylums meant to contribute to social order. Poor people were encouraged to work for the specific purpose of participating in the economic prosperity of society. Foucault added that during the 19th century, the secularization of the charitable movement with philanthropy saw a continuation of strategies designed to maintain social order (Foucault, 1980). With the objectives of regulation and normalization, mechanisms of power were invested in bodies to manage the conduct and behaviour of individuals. Health professionals had specific functions of visiting, assisting, and moralizing the "good" poor so as to promote and preserve the social order. As Foucault (1980) pointed out,

During certain periods there appear agents of liaison. Take the example of philanthropy in the early nineteenth century: people appear who make it their business to involve themselves in other people's lives, health, nutrition, housing; then, out of this confused set of functions there emerge certain personages, institutions, forms of knowledge: public hygiene, inspectors, social workers, psychologists. And we are now seeing a whole proliferation of different categories of social work. Naturally it's medicine which has played the basic role as the common denominator. Its discourse circulated from one instance to the next. It was in the name of medicine both that people came to inspect the layout of houses and, equally, that they classified individuals as insane, criminal, or sick. But there also emerged, out of the confused matrix of philanthropy, a highly diverse mosaic comprising all these "social workers" .... The interesting thing is to ascertain, not what overall project presides over all these developments, but, how, in terms of strategy, the different pieces were set in place. (p. 62)

With this political point of view on charitable and philanthropic movements, Foucault wanted to shed light on the power relations operating within what he called an "institutional apparatus" and its technology, and establish that charitable activities (and later philanthropic movements) carried an equivocal and ambiguous character because not only did they imply certain benefits for the recipients, but they also served as an apparatus of control and surveillance (Hall, 2001).

Likewise, historian Robert Gross (2003) saw religious missions and their charitable activities as the earliest form of philanthropy. According to him, the middle of the 18th century in the United States marked the split 
between these two traditions: Charity had its interventions grounded in religion but philanthropy was focused more on social actions. Zunz (2012) analyzed how, in American society, philanthropic organizations became a powerful force in their attempts to solve social problems. He summarized three main ideas regarding philanthropic organizations. First, social actions of these associations no longer concerned the poor only, but were oriented toward society in general. Second, these associations established social reforms without the assistance of the state. Third, social reforms instituted by philanthropic organizations were founded on science (research, higher education) which allowed the management of social issues through technical and scientific approaches. Zunz (2012) pointed out that at the end of the 19th century, the number of philanthropic associations had grown rapidly, setting the stage for massive organizations like the Carnegie and Rockefeller foundations, which expanded through various activities in what Donzelot named "the social."

\section{Donzelot and the Social}

According to Donzelot (1994), the concept of "the social" was invented in France in the mid-19th century, emerging out of the reorganization of a society faced with the challenges of the republican ideal and the new democratic reality after the revolution of 1848. Donzelot (1994) argued that the social was a bridging point or an intersection between the civil and political spheres because it intended to bring concrete solutions to the problems of organization in societal life. In order to cope with social problems, direct interventions supporting social change were needed. The social became then a common criterion of all policies and ensured that democratic societies were governable.

For Gordon (1991), Foucault's concept of civil society, defined as a "transaction" or as a game between government and the governed, had its confirmation in Donzelot's concept of "the social." Spector (2006) noted that in Foucault's analysis of civil society, Foucault discovered the invention of the social (italics original), which highlighted new complex relations between the social and relations of power (p. 6). Identified first as a political society, civil society, according to Foucault, was associated with the state in the second half of 18th century and appeared as a new measure intended to govern homo economicus. From a Foucauldian perspective, the early conception of civil society needs to be understood as a technique of subjectivation of individuals who thus became governable (Burchell,
1991). One can recognize here the different traits of what Foucault later identified as governmentality.

Within a social perspective, individuals were expected to develop their autonomy and become involved collectively in society through solidarity. Elaborated by French sociologist Émile Durkheim and developed into a political doctrine by other sociologists like Léon Duguit and Léon Bourgeois, the concept of solidarity provides a framework and a means for state intervention. Solidarity relied on the need for restorative actions to maintain individuals in a durable state of prosperity and security, and as such, it contributed to the reinforcement of the social role and power of the state (Donzelot, 1994). Moreover, solidarity was the foundation and an essential component of the welfare state. Welfare ideology makes the state responsible for the well-being of the population and the future of society. The invention of the social created opportunities for the state to eradicate sources of misery and oppression, to strengthen solidarity and social cohesion, and to solve social problems (Donzelot, 1991). As Dean (2010) argued, the social required a certain form of government that rests on the commitment of different agents, such as doctors, nurses, teachers, etc., to help improve the quality of life of a population. The social gave state criteria to provide assistance in managing individuals' behaviours and to organize their life in society. For Dean (2010), "the social, by institutions and practices like social welfare or social insurance; by actors like schoolteachers or social workers, and laws (e.g. juvenile court, family law) represents solutions to the problems of [...] government." (pp. 66-67) In our view, nurses, in their social function, also constitute such key actors in activities of government. Social practices, whose aims are "to direct, with a certain degree of deliberation, the conduct of others and oneself' (Dean, 2010, p. 52), are at the core of what Foucault called governmentality.

\section{Foucault's Concept of Governmentality}

In his later analyses of the exercise of power, Foucault (1982) explored the notion of governance and developed the concept of governmentality. Through governmentality, Foucault analysed management by the state, but he defined it above all as a "mentality" of government. Foucault (1982) explained this notion as follows:

This word [government] must be allowed the very broad meaning which it had in the sixteenth century. "Government" did not refer only to political structures or to the management of states; rather, it designated 
the way in which the conduct of individuals or of groups might be directed: the government of children, of souls, of communities, of families, of the sick. It did not only cover the legitimately constituted forms of political or economic subjection but also modes of action, more or less considered or calculated, which were destined to act upon the possibilities of action of other people. To govern, in this sense, is to structure the possible field of action of others. (p. 789-790)

By governmentality, Foucault wanted to emphasize another form of the exercise of power and highlight how, through various practices, procedures and techniques, the state ensured the government of subjects and populations (Foucault, 1994a; Rose \& Miller, 1992). For example, Foucault (2004) considered police as an instrument of government. Considering the term in its original sense, Foucault argued that its function is not repression, but the increase of power of the state and, thus ensuring the happiness of people through the care of others by the control and organization of social relations in civil society. Governmentality implies rational and regulated processes by which subjects are made autonomous and free to be governed, but also free to govern themselves. It sets conditions for people to do what they ought to do; it is a power that operates at a distance. The purpose of government is to ensure the "welfare of the population, the improvement of its condition, the increase of its wealth, longevity, health, etc." (Foucault, 1991, p. 100). For Foucault, "population" means not only a number of inhabitants per unit area; he also understands this notion as a "set of individuals having relations of coexistence between them constituting in this respect a specific reality; "Population" [...] has its conditions of existence - be it necessary elements for its survival or those that allow its development and well-being" (Foucault, 1976, p. 10, authors' translation). Life itself became an object of power and the main objective was to ensure the regulation of populations through a series of interventions, instruments, and techniques (Foucault, 1976). The concept of governmentality makes it possible to theorize a radical change in the forms of exercise of power. It brings forth a new political rationality based on specific apparatuses of government, and on a system of knowledge that can be applied directly to individuals and populations with the purpose to influence their behaviour (Holmes \& Gastaldo, 2002).

In fact, Foucault presents governmentality as a complex system of power that puts in place techniques and practices to govern and "conduct the conduct" of individuals, groups, or oneself (self-government and government of others) (Perron, Rudge, \& Holmes, 2010). Dean (2010) explained that "to conduct" means to lead or to guide; it carries the idea of calculation and the need for tactics to make citizens act in the "right manner" in the search for better ways of doing things and better ways of living. Such a perspective brings a central transformation in the conception of the exercise of power, which is no longer limited to techniques of domination and coercion, rather, it seeks to organize the population in productive ways. This shift in focus and techniques led Foucault to conceptualize it as a positive form of power that aims to invest bodies, discipline them, and make them productive in order to meet the needs of society and increase the strength and the wealth of the state. The use of such power leads the individual to act in the interest of the established order (Foucault, 1982).

Thus, through the concept of governmentality, Foucault stands out from other theorists of power and the state. At the centre of his thinking is the nationalization of society, that is, "the development of a set of concrete apparatuses, of practices through which power is materially exercised" (Lascoumes, 2004, p. 5, authors' translation). Governmentality is therefore neither the state apparatus nor the government, but it represents a new way of thinking about the state in terms of power relations and its instruments. State and power are no longer institutions; they represent forms of strategic thinking using techniques and practices to govern and direct the conduct of population. This art of governing directly targets the population as a whole. For example, mass vaccination campaigns or the regulation of birth control both spell specific modes of possible conduct for individuals with ramifications for the social and economic well-being of the whole population and the state itself (Foucault, 1991; Lascoumes, 2004). In each of these scenarios, nurses play a pivotal role, making them key agents in activities of government of populations. We will now expand on this aspect further.

\section{Nurses and the Social}

In Canada, the beginning of the 20th century showed more evidence of the social role of nurses. In fact, through the invention of the social, philanthropy, which gradually shifted away from older charitable perspectives, used social interventions to introduce certain norms of domestic hygiene, education, childbearing, etc., which made this form of powergovernmentality-effective to govern the lives of individuals and groups. Considering the need to 
provide the population with comprehensive and optimal care, including the improvement of living and housing conditions, health care, and public hygiene, the practice of community health nurses became institutionalized and nurses were involved in various social fields, such as public health and home care services. Nurses' interventions were intended to support the health and well-being of individuals, families, groups, populations, and systems and to help individuals adopt healthy lifestyle habits and apply elementary rules of hygiene (Boucher, 1934). During their visits, nurses needed to be skillful and tactful in order to bring about positive and lasting changes in families' attitudes towards health:

\section{By her repeated explanations, by her home- made demonstrations, the nurse can [...] change the mentality of our people full of prejudices. She has proven herself to be [...] the most popular educator of families. Her role is therefore one of the most important in all areas of hygiene. (Beaudoin, 1924, p. 13, authors' translation)}

Nurses performed various functions wherever they were providing care: Home visits, school inspections, control of contagious diseases, family surveys, etc. These roles placed them in a privileged position to influence and empower the population in taking charge of its own health. Through their knowledge, teaching, and advice, nurses were therefore able to influence individuals in the most intimate spheres of their lives, which confirms the social significance of their practice. In this regard, in the early 20th century, the national Commissioner of the Canadian Red Cross, J.-L. Biggar, emphasized that:

\section{I believe that we can predict the moment when organized society [...] will frankly adopt as ideal [...] universal health. [...]. What will make this new step possible? Many different agents, each working faithfully in their own sphere: statesmen and scientists, educators and publicists, doctors and ministers, all those who deal with the conduct of people's interests. But of all agents, none will have the opportunities or influence that people in the nursing profession have now and will continue to have as time goes on. (Biggar, 1930, p. 401- 402, authors' translation)}

Nurses-religious and secular-were significant actors in this social renewal. The public health nurse was described as "a messenger of hygiene and health. She [sic] brings health education from family to family for the good of the individual's members. She thus contributes to the improvement of public health conditions, economic conditions and social conditions" (AVM, p. 1, authors' translation). As stated above, through the care provided in the field of hygiene, nurses are called upon to become involved in the social and intervene in the collective existence of the population in the name of life and health, in order to address not only social problems but also economic and political conditions. Foucault notes that such practices were based on a state "health policy" grounded in social medicine. Looking after the health and bodies of individuals ensured that they were able to work and that they posed less risk to the health and safety of the population. According to Foucault (1994c), the emergence of health as a political object can be explained first by the fact that medicine has progressively freed itself from the techniques of assistance, and second, by the process that made wellbeing one of the essential objectives of political power, which was achieved through subtle games of state intervention and individual freedom determined by specific realms of scientific knowledge. Through Foucault's position, nurses can be understood as social and political agents enacting health policies that create the conditions through and by which individuals are productive and able to ensure the optimal functioning of economic and social life. For this purpose, it is recognized that:

The nurse fulfills a very humanitarian and
social role of the highest order which, in
addition to providing services to individuals,
contributes to the development of strong
solidarity among the population [...];
however, she should extend her scope
further by letting herself be attracted to
public health, of which she has become one
of the most essential pillars (emphasis added
by the author). (Boucher, 1934, p. 76-77,
authors' translation)

This quote is informative as it highlights two important points. First, the solidarity that nurses were asked to foster among the population was, according to Donzelot (1994), the great foundation of the social. Through this normative principle, nurses were invited to promote fraternity and humanitarian action, and thus strengthen social cohesion. Solidarism was conceived as a collective and general objective and therefore underpinned the welfare state. It introduced the art of governing through the regulation of the social bond. As noted by Dean and Bolton (1980) in their research on the administration of poverty and the development of nursing in England in the 19th century, "the movements for nursing, public health 
and hospital reform provided specific instances where their alliance was crucial to the development of a new relationship between the state and health" (p. 96). Gordon (1991) further stressed that "it is advisable also to keep in mind the history of this term's [solidarity] instrumental value" (p. 34, italics original).

Second, acts of solidarity emphasized nurses' essential role in the social through public hygiene. In fact, in Canada and the United States, for example, the development of the public health movement owed much to philanthropic organizations whose mission it was to promote public health throughout the world. Some historians explained the link between philanthropic organizations and nursing. For example, in Canada, the Rockefeller Foundation was involved in several areas of public health, particularly in public health school grants and public health scholarships to nurses (Desrosiers, Gaumer, \& Keel, 1989). In a broader context, Maraldo, Fagin, and Keenan (1988) noted that philanthropic associations supported the expansion of hospitals and nursing schools of various religious denominations-Catholic, Protestant or Jewish-and the funding of nursing programs, notably at Yale and Columbia schools of nursing. According to these authors, the goal of philanthropic organizations was to help nursing become a profession with a distinct knowledge and practice base.

\section{Rethinking the Social Role of Nursing}

Berman (1983) reminds us that since their inception, philanthropic foundations have promoted the development of knowledge. He noted that these foundations have given particular attention to science and education, which enabled them to play a critical role in the production and the dissemination of certain kinds of knowledge. For Berman, a salient characteristic of those foundations lies in their epistemological influence, that is, their ability to influence the way people organize their knowledge, how they view the world, and how they conduct their lives. Guilhot (2004) noted that the main ambition of philanthropic institutions was to produce knowledge that can be applied to the social in order to increase the potential for social control. In the same vein, Lefèvre (2015) clearly highlighted the unique relationship between philanthropy, science, and the social. He argued that philanthropists have invested in the definition and scientific understanding of social issues (education, public hygiene, housing, urbanization, etc.) to produce knowledge that enabled them to control the population. These analyses corroborate Foucault's analysis of philanthropic organizations as an apparatus of control and surveillance (Hall, 2001).
Additionally, the emergence of the welfare state crystallized the social question. In England in 1942, the Beveridge report, which was inspired by Keynesian economics and was referred to as the first document reflecting the main principles on the welfare state, made headlines and had repercussions across the world, particularly in North America (Whiteside, 2014). This report inspired reforms that aimed to improve the well-being of the population by maintaining and improving people's living conditions. One year later, in Canada, the Marsh Report (the Canadian version of the Beveridge Report) had similar objectives (Elson, 2007). The welfare state was described as being responsible for social progress through the dedication of resources meant to ensure well-being and eradicate misery. In order to achieve this goal, the welfare state relied on competent and expert professionals who could intervene effectively among individuals and the population. Rose (1993) argued that within the welfare state, the authority of experts was of considerable importance in order to achieve the well-being and the quality of life of the population. He stated that:

The truth claims of expertise were
highly significant here: through the
powers of truth, distant events and
persons could be governed "at arms
length": political rule would not itself
set out the norms of individual conduct,
but would install and empower a
variety of "professionals" who would,
investing them with authority to act as
experts in the devices of social rule.
[...]. In the name of social and
personal well-being, a complex
apparatus of health and therapeutics
has been assembled, concerned with
the management of the individual and
social body as a vital national
resource, and the management of
"problems of living," made up of
techniques of advice and guidance,
medics, clinics, guides and counsellors.
(p. 285)

These experts recognised themselves as protectors of the interests and rights of individuals and populations. For example, physicians and other health professionals such as nurses had acquired the power to determine the type of health care that should be provided to individuals and society in general. Nurses became key agents at the social level. Through initiatives meant to train nurses and send them out as missionaries to combat illness, poverty, and faithlessness, particularly in impoverished communities, it was hoped that 
nurses, because of their scientific education and expertise, would have significant impact on the poor. Nurses were thus able to influence the behaviours of the people for whom they cared due to their ability to get to know patients in their personal family settings and the intimate knowledge that they gatheredknowledge and continuous contact that are available to no other professional group. Nurses therefore had to foster trusting relationships with patients and their families. When they succeeded in fulfilling various tasks and becoming fully integrated in people's social lives, they acquired a prominent position in the community, a high social standing founded on their knowledge and specific expertise (Foth \& Holmes, 2017; Holmes \& Gastaldo, 2002).

Illich (1977) has taken special interest in those professions that have gained the power and authority to determine what the health needs of individuals and populations are and what care must be provided. In his view, these were "dominant, established or disabling professions" (p. 360). He argued that these professionals:

\section{Tell you what you need. They claim the power to prescribe. They not only advertise what is good, but order what is right. Neither high income nor long training nor delicate tasks nor social standing is the mark of the professional, but it is his power to determine what shall be needed by his client. (Illich, 1977, p. 361)}

Health policies that require increasing nursing expertise and broader competences strengthen nurses' influence and power in the realm of the social. This expertise enables them also to participate in the monitoring and the normalization of the behaviour of individuals, the regulation of the population, and more broadly, the government of citizens in their specific individuality. Nurses possess a scientific "savoir" and expertise that is largely accepted as true. The valorization of scientific knowledge in the nursing profession furthers nurses' strategic position with regards to social matters. This position makes them a powerful group in the health care system because they are in direct contact with individuals, communities, groups, and populations and are able to teach, support, advise, and coach individuals through competent interventions. The notion of "government at a distance" is of particular relevance for nursing (Foth, 2013). Through significant numbers of skills and techniques nurses are able to gather information, produce and disseminate knowledge, and participate in therapeutic encounters (Holmes \& Gastaldo, 2002).
Through caring practices, nurses both alleviate suffering of individuals and communities, and simultaneously construct patient identities as sick or healthy bodies. As a result, nurses' scientific knowledge and expertise consolidate and crystallize their influence with regard to the state's health objectives. In fact, health policies that demand more science and expertise have facilitated the expansion of scientific nursing and the role nurses play with the population (Foth, 2013). Nurses are therefore part of these social institutions that are at the core of governmentality.

The governmentality approach lent itself well to the historical study of the social role of nurses in the early 20 th century. It directed our attention to the meaning of the social role of charitable and philanthropic organizations and pointed to an open field of governing practices that involved non-state agents like nurses. It revealed that nursing had been the target of philanthropic programs and was directly involved in state intervention. Furthermore, rethinking the social role of nurses from this perspective revealed the genealogical links between state intervention, expert discourses, the regulation of individuals, and the social construction of the population. In addition, charitable and philanthropic organizations appeared to be a transformative means of governance.

\section{Conclusion}

Historical accounts have largely portrayed nursing in ways that emphasize their charitable and devotional practices. In this paper, we cast such charitable and social interventions as techniques of the state meant to facilitate the government of the population and, more broadly, the maintenance of social order. Though the exact date of the invention of the social is difficult to ascertain, it remains clear that the emergence of the social as a distinct field of intervention has gained in considerable importance from the mid-19th century on, providing nurses with key responsibilities that brought them to the forefront (in public health in particular) to evaluate health practices of individuals, families, and communities, educate people, and improve the health behaviours and outcomes of populations. The inscription of nursing practice as a form of power and nurses as agents of normalization and regulation of population's behaviour is a key element of the success of the state in securing and optimizing social performance, order, and wealth. When nurses in their social role provide instruction and promote hygiene, for example, they fully participate in the administration of the people. Nurses exercise a positive and productive power through sustained, privileged contacts with the population, thus 
facilitating the determination and upholding of social norms. Nurses' participation in the protection of health conditions of the population contributed thereby to the improvement of social and economic conditions, and these networks characterize contemporary forms of liberal (neoliberal) governance.

\section{Ethical Considerations}

Our research focused on archival documents that were consulted according to the regulations of the institutions. Forms relating to the confidentiality of the use of the documents have been signed.

\section{References}

Archives Ville de Montréal (AVM). (1958). 240 anges-gardiens veillent sur la santé des enfants par Hervé Lépine, Fonds du Comité de santé - Bureau de santé (VM 045-800.3), $1-2$.

Beaudoin, J.-A. (1924). La coupe commune. La Veilleuse, 1(7), 13-15.

Berman, E. H. (1983). The influence of the Carnegie, Ford, and Rockefeller foundations on American foreign policy: The ideology of philanthropy. Albany: State University of New York.

Biggar, J.-L. (1930). La civilisation et la santé. La Garde-Malade Canadienne-Française 3(8), 399-402.

Boucher, S. (1934). L'œuvre de l'infirmière. La Garde-Malade Canadienne-Française 7(2), 76-77.

Bremner, R. H. (1956). From the depths: The discovery of poverty in the United States. New York: New York University Press.

Burchell, G. (1991). Peculiar interest: Civil society and governing: The "system of natural liberty." In G. Burchell, C. Gordon, \& P. Miller (Eds.), The Foucault Effect: Studies in Governmentality (pp. 119-150). Chicago: University of Chicago Press.

Castel, R. (1995). Les métamorphoses de la question sociale: Une chronique du salariat. Paris: Fayard.
Cohen, Y. (2010). Femmes philanthropes: Catholiques, Protestantes et Juives dans les organisations caritatives du Québec. Montréal: Champ Libre.

Dean, M. \& Bolton,G. (1980). The administration of poverty and the development of nursing practice in nineteenth- century England. In C. Davies (Ed.), Rewriting nursing history (pp. 76-101). London: Barnes \& Noble Books.

Dean, M. (2010). Govermentality: Power and rule in modern society. London: Sage.

Desrosiers, G., Gaumer, B., \& Keel, O. (1989). L'évolution des structures de l'enseignement universitaire spécialisé de santé publique au Québec : 1899-1970. Bulletin Canadien d'Histoire de la Médecine, 6, 3-26.

Donzelot, J. (1994). L'invention du social: Essai sur le déclin des passions politiques. Paris: Éditions du Seuil.

Donzelot, J. (1991). Mobilizing of society. In G. Burchell, C. Gordon, \& P. Miller (Eds.), The Foucault effect: Studies in governmentality (pp. 169-180.). Chicago: University of Chicago Press.

Elson, P. R. (2007). A short history of voluntary sector-government relations in Canada. The Philanthropist, 21, 36-74.

Foth, T., \& Holmes, D. (2017). Neoliberalism and the government of nursing through competencybased education. Nursing Inquiry, 24(2), 1-9.

Foth, T., Kuhla, J., \& Benedict, S. (2014). Nursing during National Socialism. In S. Benedict, \& L. Shields (Eds.), Nurses and midwives in Nazi Germany: The "Euthanasia Programs" (pp. 27-47). New York: Routledge Taylor and Francis Group.

Foth, T. (2013). Understanding 'caring' through biopolitics: The case of nurses under the Nazi regime. Nursing Philosophy, 14(4), 284-294.

Foucault, M. (1975). Surveiller et punir: Naissance de la prison. Paris: Éditions Gallimard.

Foucault, M. (1976). La politique de la santé. In M. Foucault, B. Kriegel, A. Thalamy, F. Buégin, \& B. Fortier (Eds.), Machines à guérir: Aux origines de l'hôpital moderne (pp. 10-15). Paris: Institut de l'Environnement. 
Foucault, M. (1980). Body/Power. In G. Collin (Ed.), Power/knowledge: Selected interviews and other writings, 1972-1977 (pp. 55-62). New York: Vintage.

Foucault, M. (1982). The subject and power. Critical Inquiry, 8(4), 777-795.

Foucault, M. (1991). Governmentality. In G. Burchell, C. Gordon, \& P. Miller (Eds.), The Foucault effect: Studies in governmentality (pp. 87-104.). Chicago: University of Chicago Press.

Foucault, M. (1994a). La gouvernementalité. In M. Foucault, Dits et Écrits (Vol. 3, pp. 663667). Paris: Gallimard.

Foucault, M. (1994b). L'incorporation de l'hôpital dans la technologie moderne. In M. Foucault, Dits et écrits (Vol. 3, pp. 508521). Paris: Éditions Gallimard.

Foucault, M. (1994c). La naissance de la médecine sociale. In M. Foucault, Dits et Écrits (Vol. 3, pp. 207-228). Paris : Éditions Gallimard.

Foucault, M. (2004). Sécurité, territoire, population : Cours au Collège de France, 1977-1978. Paris: Seuil/Gallimard.

Gordon, C. (1991). Governmental rationality: An introduction. In G. Burchell, C. Gordon, \& P. Miller (Eds.), The Foucault effect: Studies in governmentality (pp. 1-53). Chicago: University of Chicago Press.

Gross, R. A. (2003). Giving in America: From charity to philanthropy. In L. Friedman, \& M. D. McGarvie (Eds.), Charity, philanthropy and civility in American history (pp. 29-48). Cambridge: Cambridge University Press.

Guilhot, N. (2004). Une vocation philanthropique. Actes de la Recherche en Sciences Sociales, 1, 36-48, doi : 10.3917/arss.151.0036.

Hall, S. (2001). Foucault: Power, knowledge and discourse. In M. Wetherell, S. Taylor, S. J. Yates (Eds.), Discourse, theory and practice: A reader (pp. 72-81). London: Sage Publications.

Hall, P. D. (1992) A historical overview of philanthropy, voluntary associations, and non-profit organizations in the United States, 1600-2000. In P. Hall, Inventing the nonprofit sector and other essays on philanthropy, voluntarism, and non-profit organization (pp. 32-65). Baltimore: John Hopkins University Press.

Holmes, D. \& Gastaldo, D. (2002). Nursing as means of governmentality. Journal of Advanced Nursing, 38, 557-565.

Illich, I. (1977). Disabling professions: Notes for a lecture. Contemporary Crises, 1, 359-370.

Kreutzer, S. (2010). Nursing body and soul in the parish: Lutheran deaconess motherhouses in Germany and the United States. Nursing History Review, 18, 134-50

Lascoumes, P. (2004). La gouvernementalité : De la critique de l'état aux technologies du pouvoir. Le Portique, 13-14, 2-13.

Lefèvre, S. (2015). Pour une approche sociopolitique de la philanthropie financière : plaidoyer pour un programme de recherche. Politiques et Sociétés, 34, 61-85. doi:10.7202/1032507ar.

Maraldo, P. J., Fagin, C., \& Keenan, T. (1988). Nursing and private philanthropy. Health Affairs, 7, 130-136.

O’Brien, M. E. (2008). Spirituality in nursing: Standing on holy ground (3rd Ed). Sudburry, MA: Jones \& Bartlett Publishers.

Paul, P. (1994). The contribution of the Grey nuns to the development of nursing in Canada: Historiographical issues. Canadian Bulletin of Medical History, 11, 207-217.

Perron, A., Rudge, T., \& Holmes, D. (2010). Citizen minds, citizen bodies: The citizenship experience and the government of mentally ill persons. Nursing Philosophy, 11, 100111, doi10.1111/j.1466-769X.2010.00437. $\mathrm{x}$.

Petitat, A. (1989). Les infirmières : De la vocation à la profession. Montréal: Boréal.

Rose, N., \& Miller, P. (1992). Political power beyond the state: Problematics of government. British Journal of Sociology, 43, 173-205.

Rose, N. (1993). Government, authority and expertise in advanced liberalism. Economy \& Society, 22(3), 283-299.

Sioban, N. (2011). Say little, do much: Nurses, nuns and hospitals in the nineteenth century. Philadelphia: University of Pennsylvania Press. 
Spector, C. (2006). Foucault, les lumières et l'histoire: L'émergence de la société civile. Lumières, 8, 169-191.

Whiteside, N. (2014). The Beveridge report and its implementation: A revolutionary project? Histoire@Politique,3(24): 24-37.

Zunz, O. (2012). Philanthropy in America: A history. Princeton: Princeton University Press. 